\title{
Effects of predation by Hydra (Cnidaria) on cladocerans (Crustacea: Cladocera)
}

\author{
Ligia RIVERA-DE LA PARRA, ${ }^{1}$ S.S.S. SARMA, ${ }^{2 *}$ Sarma NANDINI ${ }^{2}$
}

${ }^{1}$ Posgrado en Ciencias Biológicas, Universidad Nacional Autónoma de México, Ciudad Universitaria, Circuito de Posgrados, CP 04510, Ciudad de México; ${ }^{2}$ Laboratorio de Zoología Acuática, División de Investigación y Posgrado, Universidad Nacional Autónoma de México, Campus Iztacala, Av. de los Barrios \# 1, Los Reyes Iztacala, Tlalnepantla, CP 54090, México

*Corresponding author: sarma@unam.mx

\begin{abstract}
Planktonic cladocerans have evolved different strategies to avoid predation from vertebrates; these include changes in morphology, behavior, physiology, and/or life-history traits. However, littoral cladocerans are better adapted to avoid invertebrate predation particularly from insect larvae by evolving morphological and physiological adaptations. Nevertheless, this has not been proven for some littoral predators such as Hydra. In this study, we provide quantitative data on how Hydra affects its zooplankton prey. We studied the predation behavior on Alona glabra, Ceridodaphnia dubia, Daphnia pulex, Daphnia $c f$. mendotae, Diaphanosoma birgei, Macrothrix triserialis, Moina macrocopa, Pleuroxus aduncus, Scapholeberis kingi, Simocephalus serrulatus, Elaphoidella grandidieri, Brachionus rubens and Euchlanis dilatata. We also tested the indirect effect of allelochemicals from Hydra on the demography of Daphnia cf. mendotae. Littoral cladocerans are specially adapted to resist nematocyst injection and discharge of toxic substances from Hydra. A significant decrease in the population growth rate of $\mathrm{D}$. cf. mendotae from 0.21 to $0.125 \mathrm{~d}^{-1}$ was observed at Hydra densities of 2 ind. $m L^{-1}$. The role of carapace thickness as an adaptive strategy of littoral cladocerans against Hydra predation is discussed.
\end{abstract}

Key words: Allelochemicals; invertebrate predation; nematocysts; predator-prey interactions; zooplankton.

Received: April 2015. Accepted: October 2015.

\section{INTRODUCTION}

Predation is one of the most important interactions in aquatic systems regulating distribution and abundance of aquatic species (Murdoch and Bence, 1987). Among the freshwater invertebrate predators in the littoral zone, Hydra is attached to substrates, such as macrophytes, dead leaves, stems, dead sticks and rocks (Massaro et al., 2013). Hydra has a wide geographical distribution and occurs on all continents except Antarctica (Jankowski et al., 2008). In spite of this wide distribution, it has received little attention from the ecologists. During the last 30 years Web of Science reports as many as 3000 papers on Hydra, yet $<6 \%$ of them deal with ecological aspects; most of the articles are focused on biochemistry, cell biology, and genetic aspects. It is known that Hydra is a predator, but it could have much stronger influence on the prey than is thought because of its reproductive capacity, predation strategies and high longevity $(>1$ year) (Slobodkin and Bossert, 2010).

The preferred prey items of Hydra include many crustaceans, mainly cladocerans and copepods and some insect larvae and annelids (Massaro et al., 2013). The predator-prey interaction between Hydra and its prey could be direct or indirect. Direct interaction implies a physical encounter in which the predator kills the prey eliminating it from the system, while indirect interaction is regulated by chemical cues where the predator releases allelochemicals which are sensed by the prey or even a competitor, and thus modifies its behavior, morphology or life history traits (Harvell, 1990; Larsson and Dodson, 1993; Lass and Spaak, 2003). However, it is important to mention that these indirect responses of prey to allelochemicals from Hydra have not been adequately considered in the literature.

Zooplankton species that live in the littoral zone have evolved defense mechanisms as a result of long-term coexistence in the shallow weedy zones of water bodies with their predators (Åbjörnsson et al., 2004). Such mechanisms could involve, in the case of Hydra, reducing activation of nematocysts, some kind of immunity to the toxin or resistance to nematocyst penetration through the carapace thickness (Schwartz et al., 1983). The latter could be tested in prey species with strongly built carapaces such as Simocephalus and chydorids and with smoother ones like Daphnia, Diaphanosoma, and Moina (Dodson and Frey, 2001; Dumont and Negrea, 2002). There are several methods to study predator prey interactions (Greene, 1983; Krebs, 1985, 1999). These include observational approaches such as: i) feeding behavior where one can quantify number of occurrences of encounters, attacks, captures, and ingestions, as well as the time required for prey ingestion or digestion; experimental methods such as ii) feeding preferences; iii) functional and numerical responses; and iv) life table demography to compare the 
survivorship and reproduction-related effects of allelochemicals from the predators on the prey.

In this study we: i) examined the vulnerability of cladocerans to Hydra predation; ii) related the cladoceran vulnerability to their habitat; and iii) explored the possibility that allelochemicals from Hydra had an influence on the life history traits of the cladoceran Daphnia cf. mendotae. This would increase our understanding of the role of Hydra in aquatic ecosystems. We hypothesize that in contrast to pelagic species, littoral ones would be less damaged by Hydra attack, and that allelochemicals from this cnidarian could have significant effects on the life history traits of its prey.

\section{METHODS}

\section{Culturing Hydra and its prey}

For the observations and the experiments, we isolated 13 prey species from a few waterbodies located in the State of Mexico (Tab. 1), that were later mass-cultured starting with a single parthenogenetic female; cladocerans: Alona glabra Sars, Ceriodaphnia dubia Richard, Daphnia pulex Leydig, Daphnia cf. mendotae Birge, Diaphanosoma birgei Korinek, Macrothrix triserialis (Brady), Moina macrocopa (Straus), Pleuroxus aduncus (Jurine), Scapholeberis kingi Sars, Simocephalus serrulatus (Müller); copepods: Elaphoidella grandidieri (Guerne and Richard), and rotifers: Brachionus rubens Ehrenberg and Euchlanis dilatata Ehrenberg.

For mass cultures, as well as the experiments we used standard EPA medium, a medium that is frequently employed to culture rotifers and cladocerans (Weber, 1993). The EPA medium was prepared by dissolving $96 \mathrm{mg}$ $\mathrm{NaHCO}_{3}, 60 \mathrm{mg} \mathrm{CaSO}_{4}, 60 \mathrm{mg} \mathrm{MgSO}_{4}$, and $4 \mathrm{mg} \mathrm{KCl}$ in $1 \mathrm{~L}$ of distilled water. The prey species were all fed daily using the single-celled green alga Chlorella vulgaris at $0.5 \times 10^{6}$ cells $\mathrm{ml}^{-1}$. Alga was mass-cultured in $2 \mathrm{~L}$ trans- parent bottles using Bold's basal medium (Borowitzka and Borowitzka, 1988). The predator, Hydra, was isolated from a pond at Dolores Village, Tepotzotlán (State of Mexico) (1943'34.41'N, 99²4'26.94”'W), and was cultured in $10 \mathrm{~L}$ aquaria containing $8 \mathrm{~L}$ of EPA medium and was fed every three days using Moina macrocopa and $\mathrm{Ce}$ riodaphnia dubia.

\section{Feeding behavior}

We offered eight prey cladocerans (Ceriodaphnia dubia, Daphnia pulex, Daphnia cf. mendotae, Macrothrix triserialis, Moina macrocopa, Pleuroxus aduncus, Scapholeberis kingi, and Simocephalus serrulatus) to Hydra. The experiments were performed during a 45-min observational period in Petri dishes $(50 \mathrm{mmx} 15 \mathrm{~mm})$ containing $10 \mathrm{~mL}$ medium and one individual of Hydra and 10 individuals of the selected prey. For each prey species, we set up three replicates. For a given prey species, the feeding behavior of the predator (number and duration of prey encounter (E), attack (A), capture (C), ingestion (I) and the number killed (K)) was recorded (Greene, 1983). Based on these data, we obtained the handling time (duration from encounter through ingestion) and correlated it with the body size of the prey.

\section{Food preference}

For this experiment, we used the following prey: Alona glabra, Daphnia cf. mendotae, Diaphanosoma birgei, Macrothrix triserialis, Moina macrocopa, Scapholeberis kingi, Elaphoidella grandidieri, Brachionus rubens, and Euchlanis dilatata. Hydra was pre-starved for $24 \mathrm{~h}$ prior to the initiation of the experiments. All nine prey items were individually introduced into a Petri dish (50 mmx15 mm) containing $20 \mathrm{~mL}$ EPA medium and later two individuals of Hydra were placed into the same container. Cladocerans and copepods were introduced at 1.75 ind. $\mathrm{mL}^{-1}$ (per species) and rotifers at 1.5 ind. $\mathrm{mL}^{-1}$ (per

Tab. 1. Water bodies from which different prey species were isolated.

\begin{tabular}{|c|c|}
\hline Species & Waterbody (Coordinates) \\
\hline Alona glabra & Xochimilco $\left(19^{\circ} 17^{\prime} 17^{\prime \prime N}, 9^{\circ} 06^{\prime} 05^{\prime \prime} \mathrm{W}\right)$ \\
\hline Ceriodaphnia dubia & Presa Benito Juárez (1941’22’N, 99²5’38’W) \\
\hline Daphnia pulex & Xochimilco $\left(19^{\circ} 17^{\prime} 17^{\prime \prime} \mathrm{N}, 99^{\circ} 06^{\prime} 05^{\prime \prime} \mathrm{W}\right)$ \\
\hline Daphnia cf. mendotae & Presa Benito Juárez (1941’22”N, 99²5’38”W) \\
\hline Diaphanosoma birgei & Lirios (19³9’10’'N, 99¹3’14’’W) \\
\hline Macrothrix triserialis & Xochimilco $\left(19^{\circ} 17^{\prime} 17^{\prime \prime} \mathrm{N}, 9^{\circ} 06^{\prime} 05^{\prime \prime} \mathrm{W}\right)$ \\
\hline Moina macrocopa & Xochimilco $\left(19^{\circ} 17^{\prime} 17^{\prime \prime} \mathrm{N}, 9^{\circ} 06^{\prime} 05^{\prime \prime} \mathrm{W}\right)$ \\
\hline Pleuroxus aduncus & Presa Benito Juárez (1941’22’”N, 99²5’38’W) \\
\hline Scapholeberis kingi & Presa Benito Juárez (1941’22’N, 99²5’38’”) \\
\hline Simocephalus serrulatus & Presa Benito Juárez (1941’22’”N, 99²5’38’’W) \\
\hline Elaphoidella grandidieri & Fish farm, Cuautla (1849’28’’N, 9856’23”W) \\
\hline Brachionus rubens & Xochimilco $\left(19^{\circ} 17^{\prime} 17^{\prime \prime} \mathrm{N}, 9^{\circ} 06^{\prime} 05^{\prime \prime} \mathrm{W}\right)$ \\
\hline Euchlanis dilatata & Presa Benito Juárez (1941’22”N, 99²5’38”W) \\
\hline
\end{tabular}


species). These experiments were conducted using ten replicates and at two temperatures $\left(15^{\circ} \mathrm{C}\right.$ and $\left.25^{\circ} \mathrm{C}\right)$. After initiation and $2 \mathrm{~h}$ of feeding, the predators were removed and the uneaten prey individuals were fixed in 5\% formalin. Later, the number of prey items left in the test jars was quantified and based on the difference between the initial and final prey density, we calculated the number consumed per predator. To calculate the food preference, we used the Manly's $\alpha$ index (Krebs, 1999).

\section{Demographic experiments using allelochemicals from Hydra}

The demographic experiments were conducted in jars with $50 \mathrm{~mL}$ of EPA medium containing 10 neonates of Daphnia cf. mendotae $(<24 \mathrm{~h})$ per jar, and at one of four densities of Hydra (0 (=control), 0.1, 0.2, and 2 ind. $\mathrm{mL}^{-1}$ ). The Hydra population was fed using Moina macrocopa. Throughout the experimental period, the test jars contained both, the prey and the predator, but latter was separated from the former by a small mesh $(70 \mu \mathrm{m}$ pore size) placed inside the test jars so as to prevent the direct attack on the prey by Hydra. Chlorella at a concentration of $0.5 \times 10^{6}$ cells $\mathrm{mL}^{-1}$ was used as food for daphniids in the test jars. For each treatment we set up four replicates (cohorts). Daily we counted the number of original cohort alive and the number of neonates born, if any. Later, the dead individuals and neonates were discarded and the surviving adults were transferred to fresh jars containing appropriate test combinations. The experiments were discontinued when every individual of the original cohort had died. From the data on survival and reproduction, we derived standard demographic variables (mean lifespan, gross and net reproductive rates, generation time and the rate of population increase) following Krebs (1985).

\section{RESULTS}

\section{Feeding behavior}

The prey handling time by Hydra was significantly (corr. coefficient $=0.62$ ) and positively related to the body size of the prey species. The prey ingestion and digestion times were not associated with the size of the prey. As for the survival of prey after being stung by Hydra, there were no significant differences in survival with relation to prey size. However, Simocephalus and Pleuroxus were eaten alive and the survival time corresponded to the total time that elapsed between capture and ingestion (Fig. 1). Hydra encountered $D$. pulex almost once every minute, while Pleuroxus was least encountered. All captured individuals were ingested and no prey items were rejected after being captured. The relation between the number killed and number encountered was highest for Macrothrix but lowest for Pleuroxus (Tab. 2).

\section{Food preference}

The trend in prey selection by Hydra was similar at both the temperature ranges tested (Fig. 2). Thus, regardless of temperature, Diaphanosoma and Moina were the most preferred items by Hydra, while all other prey species including copepods and rotifers (Alona glabra, Daphnia cf. mendotae, Moina macrocopa, Scapholeberis kingi, Elaphoidella grandidieri, Brachionus rubens and Euchlanis dilatata) were not positively selected.

\section{Demography of Daphnia cf. mendotae}

The age-specific survivorship curves of $D$. cf. mendotae subjected to different treatments containing allelochemicals showed reduction in survival when the highest number of predators ( 2 ind. $\mathrm{mL}^{-1}$ ) was present in the test containers as compared to controls or those with lower numbers of Hydra (Fig. 3). Age specific reproductive curves of $D$. cf. mendotae also showed reduction in the number of offspring produced in the presence of Hydra at the highest density $\left(2\right.$ ind. $\mathrm{mL}^{-1}$ ). In the absence of (controls) or in lower concentrations of Hydra, the maximum number of offspring per female per day was about 3.5, while this was reduced to $1 / 3^{\text {rd }}$ in treatments containing 2 individuals of Hydra $\mathrm{mL}^{-1}$ (Fig. 3). Information on the life

Tab. 2. Feeding behavior of the predator Hydra using different cladoceran species as prey. The number of prey encountered (E), attacked (A), captured (C), ingested (I) and killed (K) have been recorded, based on a total of 3 replicates containing one predator each.

\begin{tabular}{|c|c|c|c|c|c|c|c|c|c|c|c|c|}
\hline \multirow[t]{2}{*}{ Species } & \multirow[t]{2}{*}{ E } & \multirow[t]{2}{*}{$\mathbf{A}$} & \multirow[t]{2}{*}{ C } & \multirow[t]{2}{*}{ I } & \multirow[t]{2}{*}{ K } & \multicolumn{7}{|c|}{ Feeding responses (probabilities) } \\
\hline & & & & & & $\mathrm{A} / \mathrm{E}$ & C/A & $\mathbf{I} / \mathbf{E}$ & $\mathbf{I} / \mathbf{A}$ & $\mathrm{I} / \mathrm{C}$ & $\mathbf{I} / \mathbf{K}$ & $\mathrm{K} / \mathrm{E}$ \\
\hline Scapholeberis kingi & 15 & 5 & 5 & 5 & 5 & 0.33 & 1 & 0.33 & 1 & 1 & 1 & 0.33 \\
\hline Daphnia pulex & 43 & 11 & 5 & 5 & 11 & 0.26 & 0.45 & 0.12 & 0.45 & 1 & 0.45 & 0.26 \\
\hline Moina macrocopa & 28 & 23 & 15 & 15 & 23 & 0.82 & 0.65 & 0.54 & 0.65 & 1 & 0.65 & 0.82 \\
\hline Daphnia cf. mendotae & 23 & 13 & 6 & 6 & 13 & 0.57 & 0.46 & 0.26 & 0.46 & 1 & 0.46 & 0.57 \\
\hline Simocephalus serrulatus & 21 & 4 & 4 & 4 & 4 & 0.19 & 1 & 0.19 & 1 & 1 & 1 & 0.19 \\
\hline Ceriodaphnia dubia & 20 & 15 & 15 & 15 & 15 & 0.75 & 1 & 0.75 & 1 & 1 & 1 & 0.75 \\
\hline Macrothrix triserialis & 19 & 16 & 16 & 16 & 16 & 0.84 & 1 & 0.84 & 1 & 1 & 1 & 0.84 \\
\hline Pleuroxus aduncus & 13 & 1 & 1 & 1 & 1 & 0.08 & 1 & 0.08 & 1 & 1 & 1 & 0.08 \\
\hline
\end{tabular}


history variables is presented in Fig. 4. Regardless of the treatment, the mean lifespan of $D$. cf mendotae varied from 14 to 17 days with significant differences in relation to the density of predators per jar. Gross reproductive rate and net reproductive rates decreased in the presence of 2 individuals of Hydra mL $\mathrm{mL}^{-1}$. At a predator density of 0.2 ind. $\mathrm{mL}^{-1}$, only the net reproductive rate showed a significant decrease. Generation time of $D$. cf. mendotae varied little (12-13 days) among treatments. Tukey tests showed significant differences between treatments containing 0.1 ind. $\mathrm{mL}^{-1}$ and 2 ind. $\mathrm{mL}^{-1}$ of predators. The rate of population increase per day $(r)$ of $D$. cf. mendotae varied from 0.12 to 0.21 per day. The $r$ of this cladoceran species decreased significantly ( $\mathrm{P}<0.05$, ANOVA) with increasing density of Hydra in test jars.
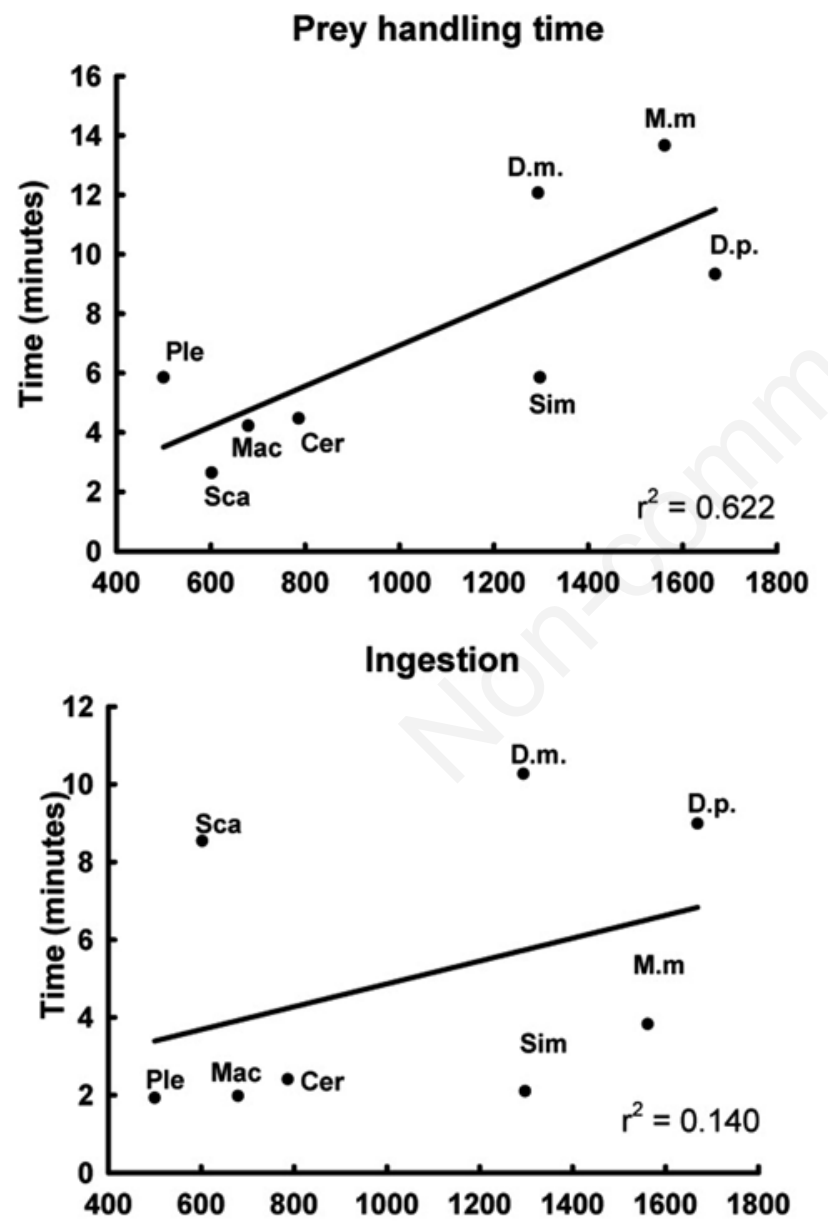

\section{DISCUSSION}

Our study demonstrated that Hydra had different effects on the zooplankton species tested here. Elliot et al. (1997) have noted that Hydra canadensis is a potential predator that can greatly reduce zooplankton communities and some vertebrates in juvenile stages. The impact caused by Hydra to its prey species depends on the density in which the predator occurs in nature. Few studies report the abundance of Hydra in nature. There are some works (Griffing, 1965; Dvorak and Best, 1982) which reported high abundances but only mentioning as fishnets covered by Hydra or high percentage of Hydra in Nitella. Hershey and Dodson (1987) quantified the natural densities of Hydra and reported as many as 10 individuals of Hydra for every $\mathrm{cm}$ of a substratum. Much earlier, Ar-
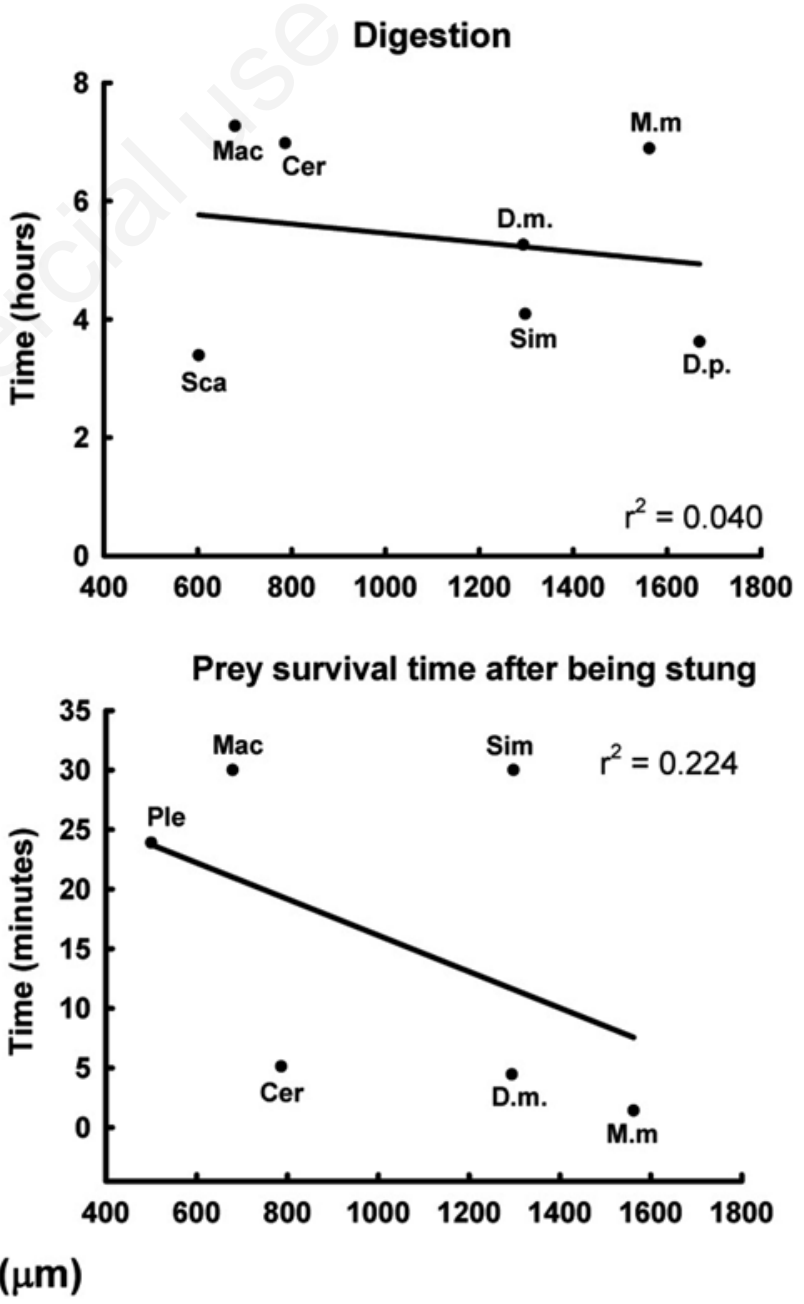

Fig. 1. Relation between prey handling time, digestion time, ingestion time and prey survival time (after being stung by $H y d r a$ sp.) and the cladoceran body size. Values are means of 3 replicates. Ple, Pleuroxus sp.; Mac, Macrothrix sp.; Cer, Ceriodaphnia sp; Sca, Scapholeberis sp.; D.m., Daphnia cf. mendotae; D.p., Daphnia pulex; M.m, Moina macrocopa; Sim, Simocephalus sp. The $\mathrm{r}^{2}$ values for each regression are shown. 
mitage and Capper (1976) also reported Hydra mean densities of up to 19 ind. $\mathrm{m}^{-3}$. This implies that Hydra can occasionally reach very high densities in a small volume and therefore its impact may have been underestimated under these conditions. For example, if we consider that one single Hydra from a density of 19 ind. $\mathrm{m}^{-3}$ could consume an average of 24 prey items day ${ }^{-1}$ (authors' personal observations), then they deplete the prey by about 456 ind. $\mathrm{m}^{-3} \mathrm{~d}^{-1}$. This is a significant number of prey consumed by an invertebrate predator, as has been reported also in another cnidarian Craspedacusta by Davis (1955), where this jellyfish consumed about 400-500 zooplankton $\mathrm{m}^{-3} \mathrm{~d}^{-1}$. Davis (1955) even remarked that with this capacity of predation, Craspedacusta could compete with planktivorous fish for food. Besides, Dodson and Cooper (1983) showed that when jellyfish reached densities of about 30 ind. $\mathrm{m}^{-3}$, their preferred prey (zooplankton) disappeared from the system. These studies suggest that the importance of predation by cnidarian predators can be much greater than is generally thought (Jankowski et al., 2005).

The nature, including the morphology, of prey items seems to be important for Hydra predation. In this study we demonstrated that Hydra was able to kill as many as 23 individuals of Moina or about 10 daphniids. However, only 1 individual of Pleuroxus was killed during the 45min observational period. There are possibly several factors responsible for this. For example, prey species may have different strategies to avoid predation; these include changes in morphology, behavior, and life history variables (Macháček, 1991; Walsh et al., 2006). For the prey used in this study, some strategies against predation, such as change in size and in various life history variables are already documented (Dodson, 1974; Burks et al., 2000). The elongation or presence of spines on species of Daphnia, Ceriodaphnia, and Macrothrix avoids predation by some invertebrate predators (Havel, 1985; Tollrian and Harvell, 1999; Nandini and Sarma, 2005). Changes in the behavior (e.g., Scapholeberis) and shift in the age at first reproduction (e.g., daphniids) due to allelochemicals from the predators have also been reported (Lass and Spaak, 2003). However, each strategy is dependent on the predator type. Carapace spines were described as having first of all a functional-morphological significance (Fryer, 1974). For example, Macrothrix possesses many spines along the ventral margin of the carapace, which helps it to avoid predation by some invertebrates such as rotifers (Asplanchnopus) and polychaetes (Aeolosoma) (Sarma et al., 2004; Nandini and Sarma, 2004, 2005). However, this defense strategy was not effective against Hydra predation. In our study Macrothrix showed the highest probability of being killed after an encounter with Hydra $(\mathrm{K} / \mathrm{E}=0.84)$. It has been observed that prey species with elongated spines such as Brachionus havanaensis and Brachionus macracanthus offer protection against preda- tion by the predatory rotifer Asplanchna because it cannot ingest them (Nandini et al., 2003). In this work, Macrothrix was easily ingested by Hydra, probably because cnidarians possess flexible tissues so that the spines of the prey do not damage them (Anderson, 2001).

The body size of the prey is yet another aspect that has received considerable attention in predator-prey interactions. It has been mentioned that the body size is crucial in prey selection by both invertebrate and vertebrate predators (Dodson, 1974). Many studies have shown that zooplankton species under predation threat reduce their body size and are thus less vulnerable to visual predators, but more vulnerable to tactile or non-visual predators (Zaret, 1980; Macháček, 1991).

In this study, even the larger species such as Moina were equally vulnerable, perhaps because larger the prey, greater was the encounter probability. This means that at least for this kind of sessile predators, size is not the main constraint in prey selection but possibly other characteristics are involved. The natural habitat (pelagic $v s$ littoral) of the prey cladoceran could be one of the factors responsible for these observed differences in vulnerability to Hydra. For example, both Moina and Diaphanosoma are pelagic species that need to avoid visual predators most of the time. So, these prey species spend their energy to evolve strategies that would help them avoid predation such as reducing body size and age at maturation, increasing clutch size, and strategies to reduce visibility or increase speed in the water column (Gliwicz, 2003; Chapparro-Herrera et al., 2011, 2013). Therefore, the development of a more robust exoskeleton is very unlikely in pelagic species because it im-

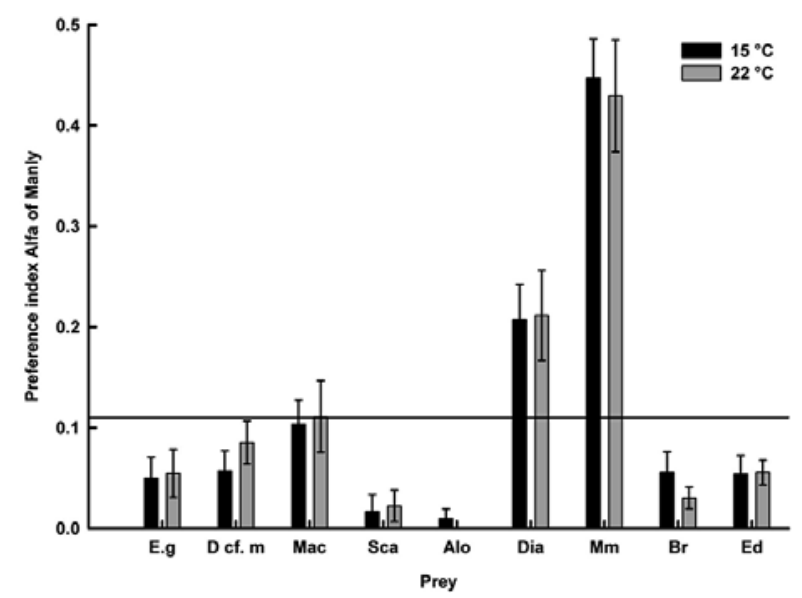

Fig. 2. Food preference ( $>0.11$, Manly'a $\alpha$ ) by Hydra on different prey species: E.g, Elaphoidella grandidieri; D cf. m, Daphnia $\mathrm{cf}$. mendotae; Mac, Macrothrix triserialis; Sca, Scapholeberis kingi; Alo, Alona glabra; Dia, Diaphanosoma birgei; Mm, Moina macrocopa; Br, Brachionus rubens; Ed, Euchlanis dilatata. The mean values \pm SE based on 10 replicates are shown. 
plies additional costs associated with increased weight during swimming (Schwartz and Hebert, 1989). Hence cladoceran species with thick carapace are more common in the littoral or benthic regions (Dodson and Frey, 2001) where they face non-visual predators. These non-visual predators such as cnidarians, turbellarians and some insect larvae have hunting strategies necessitating the manipulation of the prey items such as injecting toxic substances and sucking the internal contents (Hampton and Gilbert, 2001; Dumont, et al., 2014). Therefore, littoral prey can be expected to develop stronger and thicker carapace possibly at the cost of strong antenna muscles or other structures associated with swimming (Korovchinsky, 1992). Because of this reason, most littoral species are associated with substratum and do not necessarily swim fast or continuously in order to remain in the water column. This is evident in Chydoridae (Smirnov, 1974), for example the chydorid Anchistropus is the only predator of Hydra perhaps because of its immunity to attacks by nematocysts due to its thick carapace (Van Damme and Dumont, 2009). We would expect a similar immunity from other genera of chydorids, and this was demonstrated in this study where Pleuroxus was less vulnerable to Hydra. This is also applicable to Simocephalus, which develops thicker carapace in order to avoid invertebrate predation (Schwartz and Hebert, 1989) and which showed little vulnerability also to Hydra predation in our study. Thus, it is expected that predation by Hydra affects populations of pelagic prey reaching the littoral regions of waterbodies, either for food or shelter than the species adapted to live in these habitats.

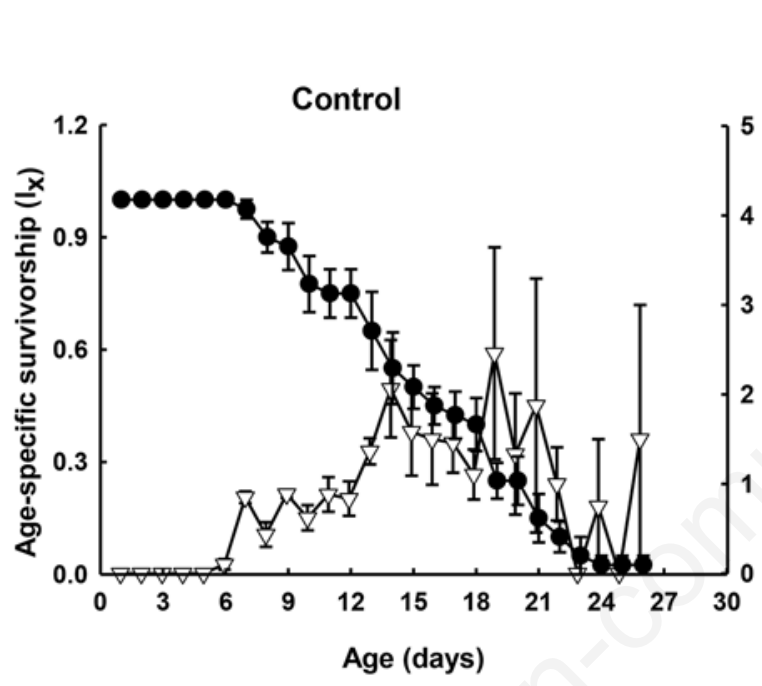

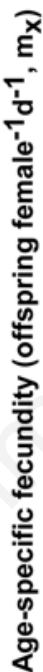

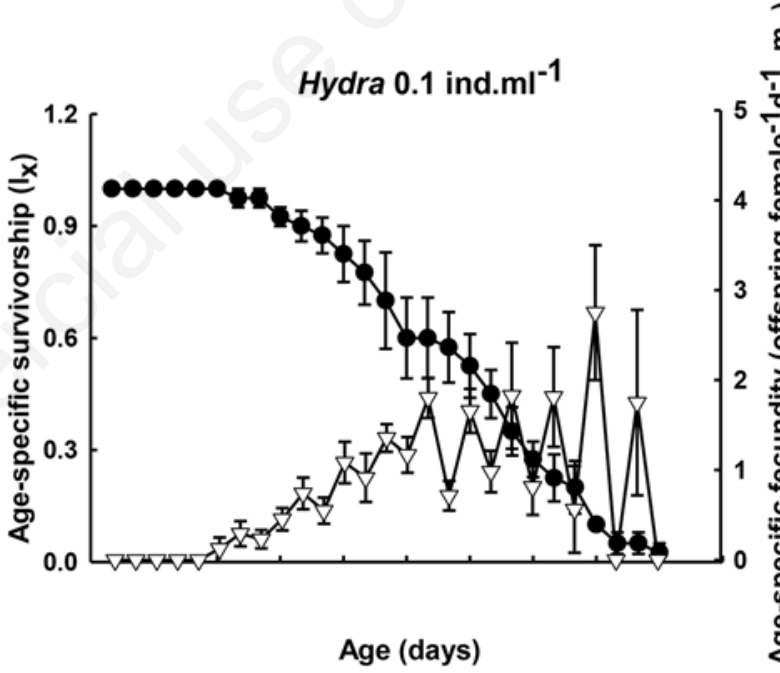

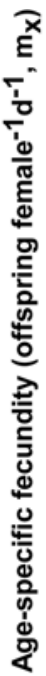
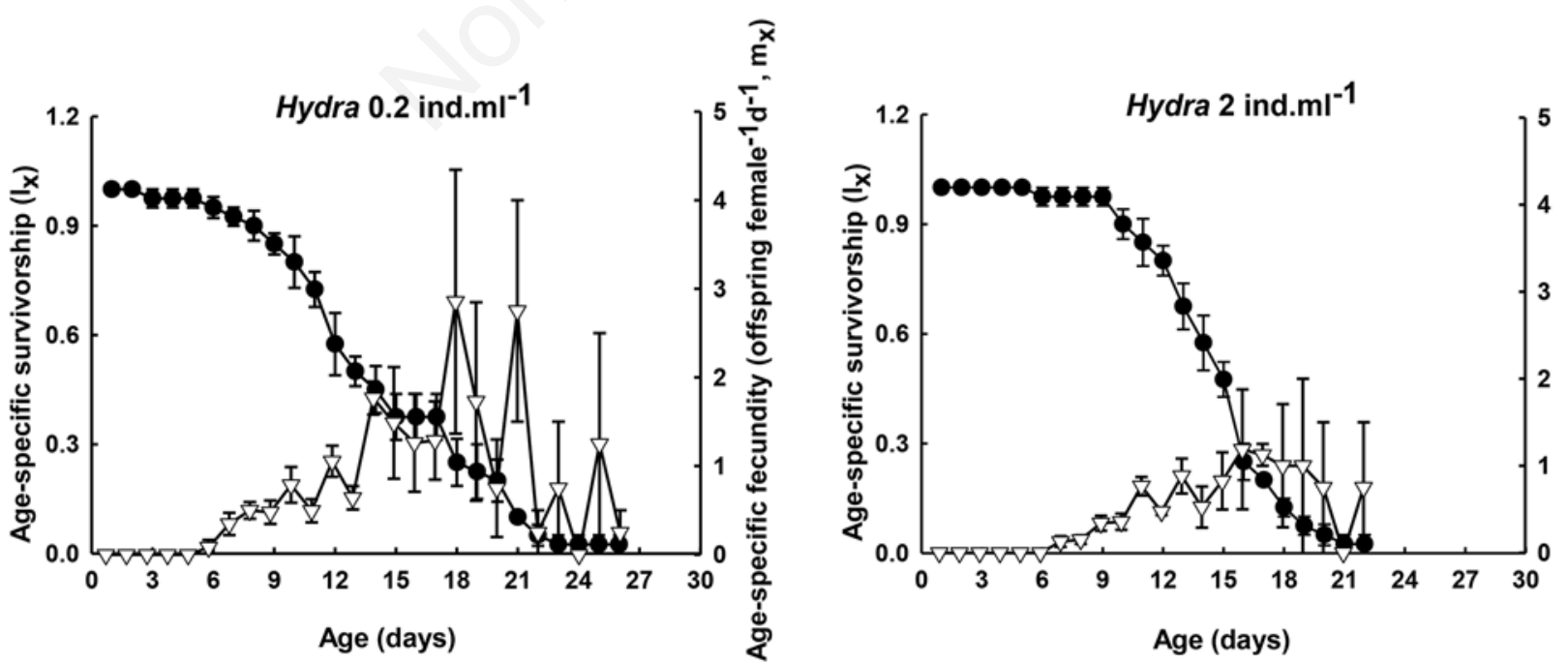

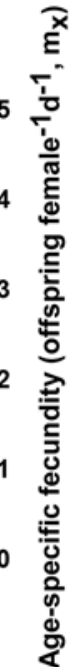

Fig. 3. Age-specific survivorship (closed circles) and fecundity (open triangles) curves of Daphnia cf. mendotae at indirect presence (allelochemicals) of Hydra at four concentrations: control, Hydra 0.1 ind. $\mathrm{mL}^{-1}$, Hydra 0.2 ind. $\mathrm{mL}^{-1}$ and Hydra 2 ind.mL $\mathrm{mL}^{-1}$ The mean values \pm SE are shown. 
In addition to these morphological strategies, the prey species may also show changes in their life history (survivorship and reproduction-related adaptions) as a result of perceiving the allelochemicals released by the predators (Gama-Flores et al., 2003; Lass and Spaak 2003; Gar- cía et al., 2007). Here we quantified the effect of allelochemicals from Hydra on the life history variables of Daphnia cf. mendotae, with which it co-occurs. Evidently daphniid survival was not strongly affected by allelochemicals from Hydra; however fertility was severely re-
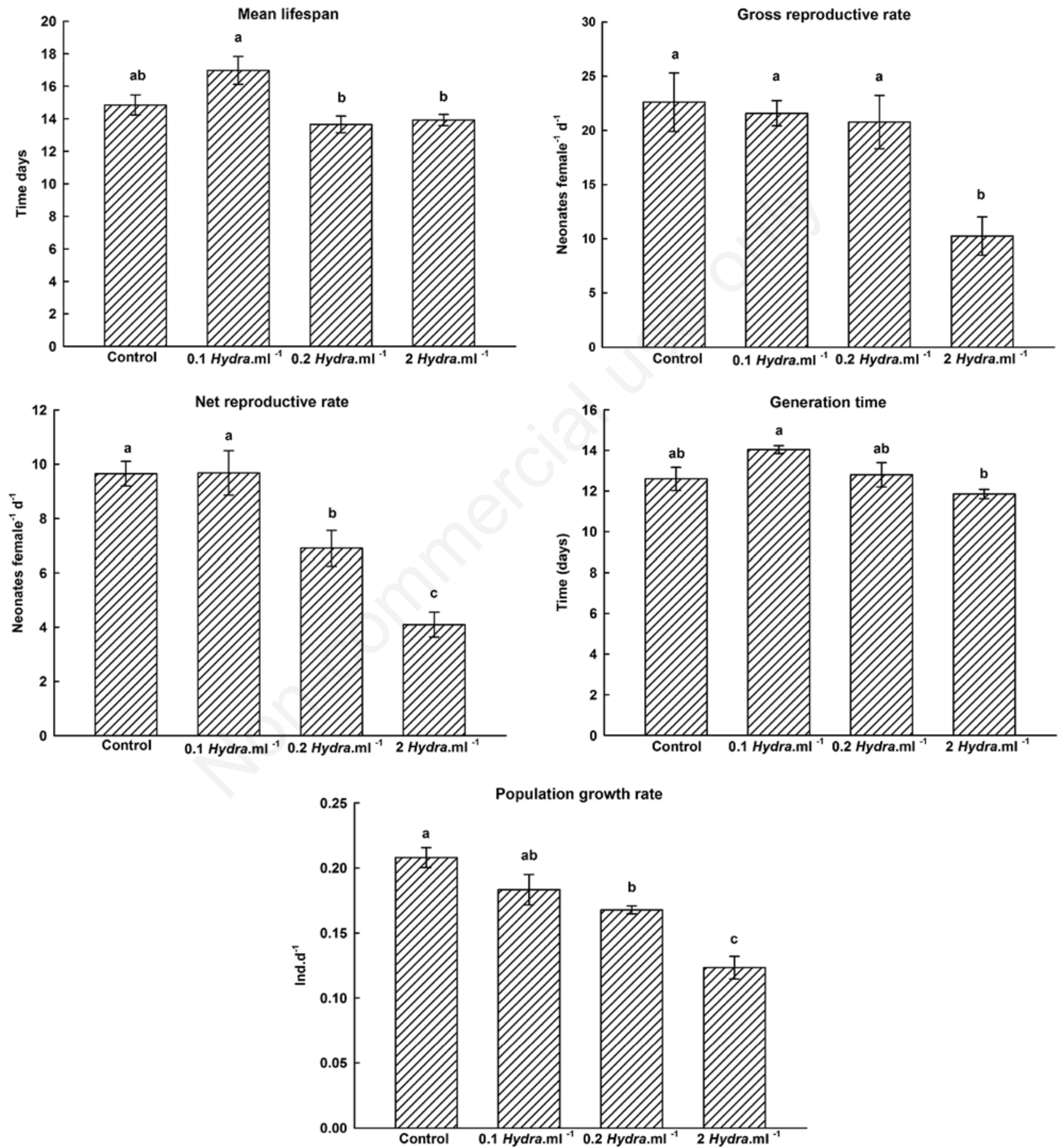

Fig. 4. Demographic variables (mean life span, gross reproductive rate, net reproductive rate, generation time and rate of population increase) of Daphnia cf. mendotae at indirect presence (allelochemicals) of Hydra under four concentrations: control, $H y d r a 0.1$ ind.mL ${ }^{-1}$, Hydra 0.2 ind. $\mathrm{mL}^{-1}$ and Hydra 2 ind. $\mathrm{mL}^{-1}$. The mean values $\pm \mathrm{SE}$ are shown. 
duced as result of the presence of the predator, especially in the treatment containing 2 ind. $\mathrm{mL}^{-1}$ of Hydra. For a number of invertebrates including zooplankton, survivorship is generally less affected due to stress than reproductive parameters (Kammenga and Laskowski, 2000). In addition, it is known that the allelochemicals of Hydra are considered as allomones where the chemical substances released by the predator cause a negative effect on prey, perhaps due to toxic characteristics, without necessarily causing a change in the morphology nor affecting the predator itself (Sher et al., 2005).

Macháček (1991) and Stibor and Lüning (1994) suggest that a reduction, due to allelochemicals from predators, in growth rates could favor reproduction. We observed that allelochemicals from Hydra affected both survivorship and reproduction of $D$. cf. mendotae. These data agree with Weider and Pijanowska (1993) who suggested that life history traits of daphniid prey are flexible depending on the source of allelochemicals (vertebrate $v s$ invertebrate predators). The allelochemicals released by Hydra may be exerting a toxic effect on daphniids which explains the decrease in the fitness of the population. The allelochemicals released by Hydra may also bring certain morphological changes in the littoral prey such as thickening of the carapace, which has already been reported as a successful strategy against certain invertebrate predators (Laforsch et al., 2004; Rabus et al., 2013).

\section{CONCLUSIONS}

In conclusion, our data showed that Hydra can exert direct and indirect effects on its prey and more so for the pelagic taxa, that reach from time to time close to the littoral zones in search of either food or as shelter from predators. Therefore in ponds where Hydra is present, the pelagic cladoceran genera such as Diaphanosoma, Daphnia, and Moina, may have reduced survival and reproductive put. Our results suggest that chydorids should be the most abundant group in ponds where Hydra is abundant. Further studies are still needed to test these relationships under natural conditions.

\section{ACKNOWLEDGMENTS}

We thank two anonymous reviewers for suggestions. The first author (LRP) is thankful to the Posgrado en Ciencias Biológicas for the training received during her studies and to CONACYT (CVU: 336216) for financial support. SSSS thanks UNAM for a project (PAPIITIA203315).

\section{REFERENCES}

Åbjörnsson K, Hansson LA, Brönmark C, 2004. Responses of prey from habitats with different predator regimes: local adaptation and heritability. Ecology 85:1859-1866.
Anderson DT, 2001. Invertebrate zoology, 2nd ed. Oxford University Press, London: 476 pp.

Armitage PD, Capper MH, 1976. The numbers, biomass and transport downstream of micro-crustaceans and Hydra from Cow Green Reservoir (Upper Teesdale). Freshwater Biol. 6:425-432.

Borowitzka MA, Borowitzka LJ, 1988. Microalgal biotechnology. Cambridge University Press, London: 477 pp.

Burks RL, Jeppesen E, Lodge DM, 2000. Macrophyte and fish chemicals suppress Daphnia growth and alter life-history traits. Oikos 88:139-147.

Chaparro-Herrera DJ, Nandini S, Sarma SSS, Zambrano L, 2011. Feeding behaviour of larval Ambystoma mexicanum. Amphibia-Reptilia 32:509-517.

Chaparro-Herrera DJ, Nandini S, Sarma SSS, 2013. Effect of water quality on the feeding ecology of the axolotl $\mathrm{Am}$ bystoma mexicanum. J. Limnol. 72:e46.

Davis CC, 1955. Notes on the food of Craspedacusta sowerbyi in Crystal Lake, Ravenna, Ohio. Ecology 36:364-366.

Dodson SI, 1974. Zooplankton competition and predation: an experimental test of the size-efficiency hypothesis. Ecology 55:605-613.

Dodson SI, Cooper SD, 1983. Trophic relationships of the freshwater jellyfish Craspedacusta sowerbyi Lankester 1880 . Limnol. Oceanogr. 28:345-351.

Dodson SI, Frey DG, 2001. Cladocera and other Branchiopoda, p. 850-914. In: J.H. Thorp and A.P. Covich (eds.), Ecology and classification of North American freshwater invertebrates. Academic Press.

Dumont H, Negrea S, 2002. Introduction to the Class Branchiopoda. Guides to the Identification of the Microinvertebrates of the Continental Waters of the World 19, Backhuys, The Netherlands.

Dumont HJ, Rietzler AC, Bo-Ping H, 2014. A review of typhloplanid flatworm ecology, with emphasis on pelagic species. Inland Waters 4:257-270.

Dvorak J, Best EPH, 1982. Macroinvertebrate communities associated with the macrophytes of Lake Vechten: structural and functional relationships. Hydrobiologia 95:115-126.

Elliot JK, Elliot JM, Leggett WC, 1997. Predation by Hydra on larval fish: Field and laboratory experiments with bluegill (Lepomis macrochirus). Limnol. Oceanogr. 42:1416-1423.

Fryer G, 1974. Evolution and adaptive radiation in the Macrothricidae (Crustacea: Cladocera): a study in comparative functional morphology and ecology. Philos. T. Roy. Soc. B 269: 137-273.

Gama-Flores JL, Huidobro-Salas ME, Sarma SSS, Nandini S, 2013. A laboratory study on the effects of allelochemicals released by vertebrates (fish, salamander and tadpole) on the life history parameters of Moina macrocopa (Cladocera). Allelopathy J. 31:415-425.

García CE, Chaparro-Herrera DJ, Nandini S, Sarma SSS, 2007. Life history strategies of Brachionus havanaensis subject to kairomones of vertebrate and invertebrate predators. Chem. Ecol. 23:303-313.

Gliwicz ZM, 2003. Between hazards of starvation and risk of predation: the ecology of offshore animals. International Ecology Institute, Oldendorf/Luhe: 379 pp.

Greene CH, 1983. Selective predation in freshwater zooplankton communities. Int. Rev. Ges. Hydrobiol. 68:297-315. 
Griffing TC, 1965. Dynamics and energetics of populations of Brown Hydra. PhD Thesis, University of Michigan, Ann Arbor, MI, USA.

Hampton SE, Gilbert JJ, 2001. Observations of insect predation on rotifers. Hydrobiologia 446/447:115-121.

Harvell CD, 1990. The ecology and evolution of inducible defenses. Quart. Rev. Biol. 65:323-340.

Havel JE, 1985. Predation of common invertebrate predators on long- and short-featured Daphnia retrocurva. Hydrobiologia 124:141-149.

Hershey AE, Dodson SI, 1987. Predator avoidance by Cricotopus: cyclomorphosis and the importance of being big and hairy. Ecology 68:913-920.

Jankowski TA, Strauss T, Ratte HT, 2005. Trophic interactions of the freshwater jellyfish Craspedacusta sowerbii. J. Plankton Res. 27:811-823.

Jankowski TA, Collins G, Campbell R, 2008. Global diversity of inland water cnidarians. Hydrobiologia 595:35-40.

Kammenga J, Laskowski R, 2000. Demography in ecotoxicology. J. Wiley \& Sons, New York: 318 pp.

Korovchinsky NM, 1992. Sididae \& Holopediidae (Crustacea: Daphniiformes). Guides to the identification of the microinvertebrates of the continental waters of the world 3. SPB Academic Publishing, The Hague: 82 pp.

Krebs CJ, 1985. Ecology: the experimental analysis of distribution and abundance. Harper and Row, New York: 800 pp.

Krebs CJ, 1999. Ecological methodology. Harper Collins Publishers, New York: 624 pp.

Laforsch C, Ngwa W, Grill W, Tollrian R, 2004. An acoustic microscopy technique reveals hidden morphological defenses in Daphnia. P. Natl. Acad. Sci. USA 101:15911-15914.

Larsson P, Dodson S, 1993. Invited review-chemical communication in planktonic animals. Arch. Hydrobiol. 129:129-155.

Lass S, Spaak P, 2003. Chemically induced anti-predator defences in plankton: a review. Hydrobiologia 491:221-239.

Macháčk J, 1991. Indirect effect on planktivorous fish on the growth and reproduction of Daphnia galeata. Hydrobiologia 225:193-197.

Massaro FC, Negreiros NF, Rocha O, 2013. A search for predators and food selectivity of two native species of Hydra (Cnidaria: Hydrozoa) from Brazil. Biota. Neotrop. 3:35-40.

Murdoch WW, Bence J, 1987. General predators and unstable prey populations, p. 17-30. In: W.C. Kerfoot and A. Sih (eds.) Predation: direct and indirect impacts on aquatic communities. University Press of New England, Hanover.

Nandini S, Pérez-Chávez R, Sarma SSS, 2003. The effect of prey morphology on the feeding behaviour and population growth of the predatory rotifer Asplanchna sieboldi: a case study using five species of Brachionus (Rotifera). Freshwater Biol. 48:2131-2140.

Nandini S, Sarma SSS, 2004. Effect of Aeolosoma sp. (Aphanoneura: Aeolosomatidae) on the population dynamics of selected cladoceran species. Hydrobiologia 526:157-163.

Nandini S, Sarma SSS, 2005. Life history characteristics of $A s-$ planchnopus multiceps (Rotifera) fed rotifer and cladoceran prey. Hydrobiologia 546:491-501.

Rabus M, Söllradl T, Clausen-Schaumann H, Laforsch C, 2013. Uncovering ultrastructural defences in Daphnia magna - An interdisciplinary approach to assess the predator-induced fortification of the carapace. PLoS One 8: e67856.

Sarma SSS, Dumont HJ, Nandini S, 2004. Interactions between the anomopod cladocerans Ceriodaphnia dubia, C. cornuta, Simocephalus vetulus and $S$. serrulatus, the aphanoneurid worm Aeolosoma sp., and the fish Skiffia lermae: predation or competition, or both? Hydrobiologia 526:147-156.

Schwartz SS, Hann BJ, Hebert PDN, 1983. The feeding ecology of Hydra and possible implications in the structuring of pond zooplankton communities. Biol. Bull. 164:136-142.

Schwartz SS, Hebert PDN, 1989. The effect of Hydra on the outcome of competition between Daphnia and Simocephalus. Biol. Bull. 176:147-154.

Sher D, Knebel A, Bsor T, Nesher N, Tal T, Morgenstern D, Cohen E, Fishman Y, Zlotkin E, 2005. Toxic polypeptides of the Hydra-a bioinformatic approach to cnidarian allomones. Toxicon 45:865-879.

Slobodkin LB, Bossert PE, 2010. Cnidaria, p. 125-142. In: J.H. Thorp and A.P. Covich (eds.) Ecology and classification of North American freshwater invertebrates. Academic Press.

Smirnov NN, 1974. Fauna of the U.S.S.R. Crustacea. Keter Publishing House, Jerusalem: 644 pp.

Stibor H, Lüning J, 1994. Predator induced phenotypic variation in the pattern of growth and reproduction in Daphnia hyalina (Crustacean; Cladocera). Funct. Ecol. 8:97-101.

Tollrian R, Harvell CD, 1999. The ecology and evolution of inducible defenses. Princeton University Press, Princeton: $395 \mathrm{pp}$.

Van Damme K, Dumont HJ, 2009. Limb morphology of the carnivorous anomopods Anchistropus emarginatus Sars, 1862 and Pseudochydorus globosus (Baird, 1843) (Crustacea: Branchiopoda: Anomopoda). Ann. Limnol.- Int. J. Lim. 43:271-284.

Walsh EJ, Salazar M, Remirez J, Moldes O, Wallace RL, 2006. Predation by invertebrate predators on the colonial rotifer Sinantherina socialis. Invert. Biol. 125:325-335.

Weber CI, 1993. Methods for measuring the acute toxicity of effluents and receiving waters to freshwater and marine organisms, 4th ed. U.S. Environmental Protection Agency, Cincinnati: 293 pp.

Weider LJ, Pijanowska J, 1993. Plasticity of Daphnia life histories in response to chemical cues from predators. Oikos 67:385-392.

Zaret TM, 1980. Predation and freshwater communities. Yale University Press, New Haven: 187 pp. 